\title{
Materialna pamięć krajobrazu cmentarzy w wyludnionych wiejskich jednostkach osadniczych polskiej części dawnych Prus Wschodnich - wybór zagadnień ${ }^{*}$
}

\author{
Anna Majewska \\ https://orcid.org/0000-0003-0589-6400 \\ Katedra Geografii Politycznej, Historycznej i Studiów Regionalnych, Wydział Nauk Geograficznych, \\ Uniwersytet Łódzki
}

A ile jest jeszcze grobów, których już nie odczytamy,
choćby ktoś otrzepat kurz z kancjonatów,
przystanąt u potężnch dębów lub rozbijat baby kamienne.
Nikt nie dostrzeże śladu po wymartych -
zabrat je język legendy.

ERWin KruK, Jeszcze, 1984

Zarys treści: W artykule przedstawiono wybrane zagadnienia dotyczące cmentarzy jako istotnych składowych niezamieszkanych współcześnie wiejskich jednostek osadniczych położonych w części byłych Prus Wschodnich włączonej do Polski w 1945 r. Podjęta została problematyka identyfikacji i rozmieszczenia miejsc pochówku na obszarze badań oraz ich położenia w środowisku geograficznym. Zagadnienia zrealizowano poprzez wykonanie komparatystycznej analizy archiwalnych i aktualnych materiałów kartograficznych oraz analiz przestrzennych z wykorzystaniem technik hGIS. Rezultaty przedstawione w opracowaniu stanowią część wyników badań nt. krajobrazowych skutków przerwania ciągłości osadnictwa, do którego doszło w miejscowościach Warmii, Mazur i Powiśla w końcowym etapie drugiej wojny światowej i po jej zakończeniu.

Stowa kluczowe: studia krajobrazowe, wyludnione miejscowości, krajobraz kulturowy, geografia historyczna, LiDAR, GIS

\section{Wprowadzenie}

„Ze wszystkich bezpowrotnych miejsc najbardziej bezpowrotne są bez wątpienia cmentarze - poniekąd już choćby dlatego,

\footnotetext{
* Opracowanie zawiera wyniki badań zrealizowanych w ramach projektu pt. „Pamięć krajobrazu zanikających miejscowości z terenu dawnych Prus Wschodnich - materialny wymiar przerwania ciagłości osadnictwa”, sfinansowanego ze środków programu grantowego Preludium 15 Narodowego Centrum Nauki nr 2018/29/N/HS3/01001 i stanowiących część przygotowywanej przez autorkę rozprawy doktorskiej na ten temat.
}

Abstract: The article discusses selected issues surrounding cemeteries as important elements of presently abandoned rural settlements located in the part of former East Prussia incorporated into Poland after 1945. It tackles the issue of identification and distribution of burial sites on the researched area and their location in the geographical environment. The discussion is based on a comparative analysis of archival and contemporary cartographic materials and spatial analyses making use of hGIS technology. The results presented in the paper constitute of a part of a study of the impact of the interruption in settlement continuity on landscape in selected localities of the regions of Warmia, Masuria, and Powiśle in the final months of World War II and after the end of the military conflict.

Keywords: landscape studies, abandoned localities, cultural landscape, historical geography, LiDAR, GIS

że są przejściem na stronę, z której nie ma powrotu" . Ich przestrzenie podlegają nieustannym przemianom, a dotyczy to wszystkich elementów składowych, począwszy od części podziemnej, stanowiącej istotę cmentarzy, po całą strukturę naziemną z roślinnością i nagrobkami.

${ }^{1}$ Cyt. za: M. Burzyńska, Miejsca nie-pamięci, „Menażeria” (http://menazeria. eu/8,przejazd.html?artykullD=168, dostęp: 8 lutego 2020). 
Wiele przekształceń ma wymiar antropogeniczny - to głównie intencjonalna kreacja, dekompozycja bądź dewastacja określają bieżący i przyszły charakter tych przestrzeni ${ }^{2}$. O kierunku zmian w znaczącym stopniu decyduje pamięć narodów, społeczności i wspólnot lokalnych, gdyż cmentarze są jej materialnymi nośnika$\mathrm{mi}^{3}$. Umiejscowione $\mathrm{w}$ ich obrębie groby są jednym z elementów konstytuujących tożsamość wspólnotową, regionalną i etniczną - przypieczętowują przynależność ziemi zamieszkiwanej przez określone grupy (mamy więc do czynienia z tzw. nekronacjonalizmem ${ }^{4}$ ). Następujący $\mathrm{z}$ różnych przyczyn rozpad wspólnot lokalnych, których dziedzictwem są poszczególne miejsca pochówku, oraz czasowe bądź trwałe przerwanie ciągłości osadnictwa wyzwalają proces zapominania, a także filtrowania i modyfikowania wcześniejszego przekazu pokoleniowego5. Gdy zabraknie pamięci indywidualnej, wspólnotowej i pokoleniowej, pewną kontynuację stanowi - niczym nieme echo - zapis krajobrazowy: roślinność, inskrypcje nagrobne i inne elementy dawnych założeń cmentarnych oraz ich położenie w przestrzeni, składające się łącznie na tzw. materialną pamięć krajobrazu tych miejsc ${ }^{6}$. Istnienie mogilników w aspekcie fizycznym, szczególnie w czasie ograniczenia bądź ustania antropopresji, zależy zatem w szczególności od trwania tego właśnie rodzaju pamięci.

Podkreślenie roli pamięci krajobrazu w analizie obiektów sepulkralnych jest

\footnotetext{
${ }^{2}$ Więcej zob. A. Majewska, Continuity and decline. Temporal expression of denominational cemeteries in contemporary times, „Acta Universitatis Lodziensis. Folia Archaeologica", 34, 2019, s. 71-96.

${ }^{3}$ M. Kula, Nośniki pamięci historycznej, Warszawa 2002. Zob. także: W. Knercer, Ślady na ziemi - cmentarze, w: Nekropolie Warmii i Mazur, red. W. Knercer, B. Wacławik, Olsztyn 2016, s. 9.

${ }^{4}$ E. Domańska, Cmentarze jako przedmiot historii ratowniczej (rescue history), W: „Ziemia skrywa kości”. Zapomniane krajobrazy pamięci - cmentarze protestanckie w Wielkopolsce po 1945 roku, red. J. Kołacki, I. Skórzyńska, Poznań 2017, s. 34.

${ }^{5}$ Więcej zob. M. Zawiła, Dziedziczynienie przedwojennych cmentarzy na terenach postmigracyjnych Polski, Kraków 2019, s. 83-84.

${ }^{6}$ Przyjęto rozumienie tego terminu przedstawione w publikacji: U. Myga-Piątek, Pamięć krajobrazu - zapis dziejów w przestrzeni, „Studia Geohistorica”, 3,2015 , s. 35 .
}

niezwykle istotne w kontekście podejmowanych w artykule zagadnień dotyczących cmentarzy, które znajdują się w wyludnionych jednostkach osadniczych położonych we włączonej do Polski części dawnych Prus Wschodnich. W końcowym etapie drugiej wojny światowej i po 1945 r. na skutek ewakuacji ludności cywilnej, przesiedleń i migracji doszło do przerwania ciągłości osadnictwa w tysiącach jednostek osadniczych przechodzącej do historii niemieckiej prowincji. W setkach $\mathrm{z}$ nich proces ten miał charakter ciągły, skutkujący utrwaleniem się w środowisku geograficznym m.in. dawnych siedlisk i cmentarzy wyludnionych założeń ruralistycznych, reprezentowanych we współczesnym krajobrazie kulturowym przez zachowane w różnym stopniu destrukty zabudowy i dróg, ślady użytkowania gruntów oraz roślinność ruderalną i pochodzącą z dawnych nasadzeń ${ }^{7}$.

Jednymi z najważniejszych elementów zagospodarowania dawnych wschodniopruskich wsi, osad, kolonii, dworów, folwarków i leśniczówek są właśnie cmentarze, stanowiące według Anny Długozimej „fenomen o charakterze historycznym, społeczno-kulturowym, a nade wszystko krajobrazowym" ${ }^{8}$. Opuszczone dziewiętnastowieczne miejsca pochówku - dawniej rozporządzane przez wspólnoty, których dziś z różnych przyczyn już nie ma - są przede wszystkim zapisami przeszłości nieodległej, dokonującej się w minionym i obecnym stuleciu - przeszłości współczesnej, będącej przedmiotem zainteresowania m.in. etnografów, historyków, geografów historycznych i archeologów (tzw. archeologii współczesności bądź archeologii nas

\footnotetext{
Zob. m.in.: A. Majewska, Depopulated localities of former East Prussia as isolated components of the landscape structure in the form of clusters of high vegetation, „Journal of Geography, Politics and Society”, 9 (4), 2019, s. 42-50; taż, Relikty zanikłych jednostek osadniczych na pograniczu mazursko-mazowieckim. Interdyscyplinarny projekt badawczy, „Acta Universitatis Lodziensis. Folia Archaeologica”, 32, 2017, s. $215-235$

${ }^{8}$ A. Długozima, Fenomen cmentarzy warmińskich i mazurskich w aspekcie ich położenia w krajobrazie, w: Nekropolie Warmii i Mazur, s. 15.
} 
samych - archaeology of $\left.u^{9}\right)$. Co więcej, przestrzenie opuszczonych miejscowości, w tym przynależnych im cmentarzy, to zapisy zarówno historii osadnictwa, jak i wydarzeń, do których doszło po jego przerwaniu.

\section{Cele i główne założenia metodologiczne}

Artykuł podejmuje temat cmentarzy znajdujących się we współcześnie niezamieszkanych wiejskich jednostkach osadniczych polskiej części dawnych Prus Wschodnich. $\mathrm{Na}$ potrzeby niniejszej analizy szeroka problematyka dotycząca tego przedmiotu badań - poruszana w szczególności w ramach studiów krajobrazowych - zawężona została do wybranych zagadnień dotyczących położenia obiektów w przestrzeni geograficznej oraz ich fizjonomii. Głównym celem badawczym jest poszerzenie stanu wiedzy na temat morfologii wyludnionych miejscowości obszaru badań w zakresie sytuowania i funkcjonowania w przestrzeni lokalnych miejsc pochówku. W ramach tak zdefiniowanego problemu celami operacyjnymi uczyniono: zidentyfikowanie i analizę rozmieszczenia cmentarzy w wyludnionych miejscowościach na obszarze badań, określenie roli ukształtowania terenu w wyborze miejsc organizacji tego rodzaju obiektów oraz ustalenie ich umiejscowienia względem dawnych siedlisk.

Zagadnienia zostały zrealizowane w ramach realnej, materialnej perspektywy studiów krajobrazowych. Narrację poprowadzono w oparciu o koncepcję pamięci krajobrazu, nawiązującą do nieantropocentrycznych kierunków i sposobów

\footnotetext{
${ }^{9}$ Badania realizowane w tym nurcie dotyczą m.in. kultury materialnej naziemnych części nowożytnych założeń cmentarnych. Zob. np. E.S. Dethlefsen, The cemetery and culture change. Archaeological focus and ethnographic perspective, w: Modern material culture and archaeology of us, ed. R.A. Gould, M.B. Schiffer, New York 1981, s. 137-160. Na gruncie polskim o badaniach prowadzonych w ramach archeologii współczesności zob. m.in.: 0 . Ławrynowicz, Archaeology of us and the local identity. An interdisciplinary context, „Acta Universitatis Lodziensis. Folia Archaeologica”, 34, 2019, s. 46; A.I. Zalewska, Archeologia czasów wspótczesnych w Polsce. Tu i teraz, w: Archeologia wspótczesności. Pierwszy Kongres Archeologii Polskiej, t. 1, red. A.I. Zalewska, Warszawa 2016, s. 21-39.
}

prowadzenia analiz pojawiających się w ramach nowej humanistyki ${ }^{10}$. Przydawanie krajobrazowi prawa do posiadania własnej pamięci jest równoznaczne z przyznaniem mu pewnego rodzaju sprawczości, którą mogą dysponować nieludzkie składniki rzeczywistości. Elementy konstytuujące krajobraz kulturowy, np. obiekty będące wytworem działalności ludzkiej i obiekty fizjograficzne, nie przechowują informacji w sposób bierny. Na skutek zachodzenia procesów naturalnych dokonuje się selekcja, modyfikacja, a także destrukcja zakodowanych wcześniej intencjonalnie treści, które podlegają przemianom niezależnym od człowieka. Materialną pamięć krajobrazu kształtują zatem w różnym stopniu ludzkie i nieludzkie czynniki, które decydują o tym, co dana przestrzeń pamięta oraz co jako obserwatorzy możemy z niej odczytać. Podejście to zdeterminowało kierunek prowadzenia analiz oscylujący wokół obserwacji i interpretacji materialnej struktury krajobrazu - w tym przypadku cmentarzy i ich miejsca w przestrzeni. Niedostatek źródeł pisanych oraz innych archiwaliów przybliżających szczegóły zakładania i funkcjonowania cmentarzy przy wiejskich jednostkach osadniczych w Prusach Wschodnich właściwie wymusza przyjęcie perspektywy innej niż budowana na tradycyjnej narracji historycznej. Oddanie głosu materialnym składnikom krajobrazu poprzez zbadanie przestrzennych kontekstów ich umiejscowienia w środowisku geograficznym oraz charakteryzujących je cech morfologicznych pozwala z kolei wnioskować na temat społecznych i kulturowych aspektów funkcjonowania przestrzeni cmentarzy.

Podejście to nie jest obce badaczom podejmującym problematykę ewangelickich założeń cmentarnych. O konieczności polegania na materialnych śladach przeszłości

\footnotetext{
${ }^{10}$ E. Domańska, Historie niekonwencjonalne. Refleksja o przeszłości w nowej humanistyce, Poznań 2006; taż, Problem rzeczy we wspótczesnej archeologii, w: Rzeczy i ludzie. Humanistyka wobec materialności, red. J. Kowalewski, W. Piasek, M. Śliwa, Olsztyn 2008, s. 27-60.
} 
i znakach krajobrazu w sytuacji zerwania przekazu pokoleniowego oraz tradycyjnych więzi społecznych pisze Iwona Liżewska we wstępie do książki Tekli Żurkowskiej poświęconej cmentarzom ewangelickim w Mazurskim Parku Krajobrazowym ${ }^{11}$. Protestanckie mogilniki jako niemi świadkowie minionych czasów przypominają o spoczywających na nich ludziach, którzy dziś „dla nas współczesnych bezimienni, nieznani i obcy”, kiedyś kształtowali otaczający krajobraz, co podkreśla ks. Marcin Kotas, pisząc o ewangelickich cmentarzach Wielkopolski ${ }^{12}$. Joanna Wałkowska studia nad funkcjonowaniem protestanckich mogilników w krajobrazie sytuuje natomiast w perspektywie archeologii krajobrazu eksplorującej w szczególności zagadnienia dotyczące procesów, które zachodzą w warunkach ograniczenia bądź ustania antropopresji ${ }^{13}$.

\section{Materiały i metody}

Identyfikacji historycznych cmentarzy na terenie całkowicie wyludnionych dziś wiejskich jednostek osadniczych w polskiej części byłych Prus Wschodnich dokonano poprzez retrospektywną analizę komparatystyczną ${ }^{14}$. Materiałem referencyjnym były ortofotomapy i kompozycje barwne zdjęć satelitarnych z lat 2016-2019, które ukazują najbardziej aktualny stan użytkowania ziemi (zasoby Głównego Urzędu Geodezji i Kartografii, a pomocniczo Google Earth). Materiał porównawczy stanowiły natomiast arkusze mapy Topographische Karte Messtischblatt $^{15} \mathrm{z}$ lat dwudziestych-czterdziestych XX w. W oparciu o te zasoby wykonano również szczegółowe analizy położenia

\footnotetext{
${ }^{11}$ I. Liżewska, Wstęp, w: T. Żurkowska, Mazurskie cmentarze. Symbole w Krajobrazie, Olsztyn 2008, s. 5.

${ }^{12}$ M. Kotas, Stowo wstępne, w: Nim catkowicie znikną. Cmentarze ewangelickie w powiecie poznańskim, red. J. Kołacki, Poznań 2018, s. 8.

${ }^{13} \mathrm{~J}$. Wałkowska, Cmentarze ewangelickie z perspektywy archeologii: problemy i możliwości badawcze, w: „Ziemia skrywa kości”, s. 93.

${ }^{14}$ Zob. J. Plit, Analiza historyczna jako źródto informacji o środowisku przyrodniczym, „Problemy Ekologii Krajobrazu”, 16, 2006, s. 219.

${ }^{15}$ Topographische Karte Messtischblatt, skala: 1:25 000, Berlin 1880-1944.
}

obiektów w środowisku geograficznym, m.in. względem siedlisk dawnych założeń ruralistycznych.

Efektem analiz są opracowania kartograficzne i schematyczno-rysunkowe, które precyzyjnie oddają sedno wyników badań dotyczących wybranych przestrzennych aspektów funkcjonowania założeń cmentarnych. Do ich opracowania wykorzystano techniki hGIS (historical GIS) umożliwiające analizę i wizualizację informacji zgromadzonych $\mathrm{w}$ bazie danych przestrzennych. W celu przybliżenia morfologicznych cech wybranych obiektów (ukształtowania terenu i granic) wykorzystano gotowe dane wysokościowe z lotniczego skanowania laserowego zrealizowanego w ramach projektu Informatycznego Systemu Osłony Kraju. Dane udostępnione autorce z Głównego Urzędu Geodezji i Kartografii w formie chmur punktów (w formacie LAS 1.2) przetworzono do postaci NMT (numerycznego modelu rzeźby terenu) w formie TIN $^{16}$ z wykorzystaniem technik i algorytmów ujawniających cechy fizykalne obiektów, które są istotne z punktu widzenia podjętej analizy.

\section{Wyniki \\ a) Identyfikacja i rozmieszczenie cmentarzy na obszarze badań}

Na terenie Prus Wschodnich, w których dominowało wyznanie ewangelicko-augsburskie, cmentarze zakładano zarówno w ośrodkach parafialnych, jak i poza nimi ${ }^{17}$. Prawo kanoniczne nie obligowało protestantów do grzebania zmarłych na cmentarzach przykościelnych -

\footnotetext{
${ }^{16}$ Model uksztattowania powierzchni terenu utworzony na podstawie triangulacji punktów pomiarowych umożliwiających poprawne odzwierciedlenie rzeźby terenu. Zob. R. Olszewski, Numeryczne modele rzeźby terenu i powierzchn statystycznych, w: GIS. Obszary zastosowań, red. B. Nowak, Warszawa 2007, s. 34-40.

${ }^{17}$ Ks. Krzysztof Bielawny podaje, że cmentarze polne położone poza kościołami zakładała również ludność polskojęzyczna, która nie była chowana na przykościelnych cmentarzach ewangelickich. K. Bielawny, Nekropolie w granicach parafii ewangelickich Nawiady, Piecki i Stara Ukta przed 1945 rokiem, „Znad Pisy”, 15, 2006, s. 162.
} 

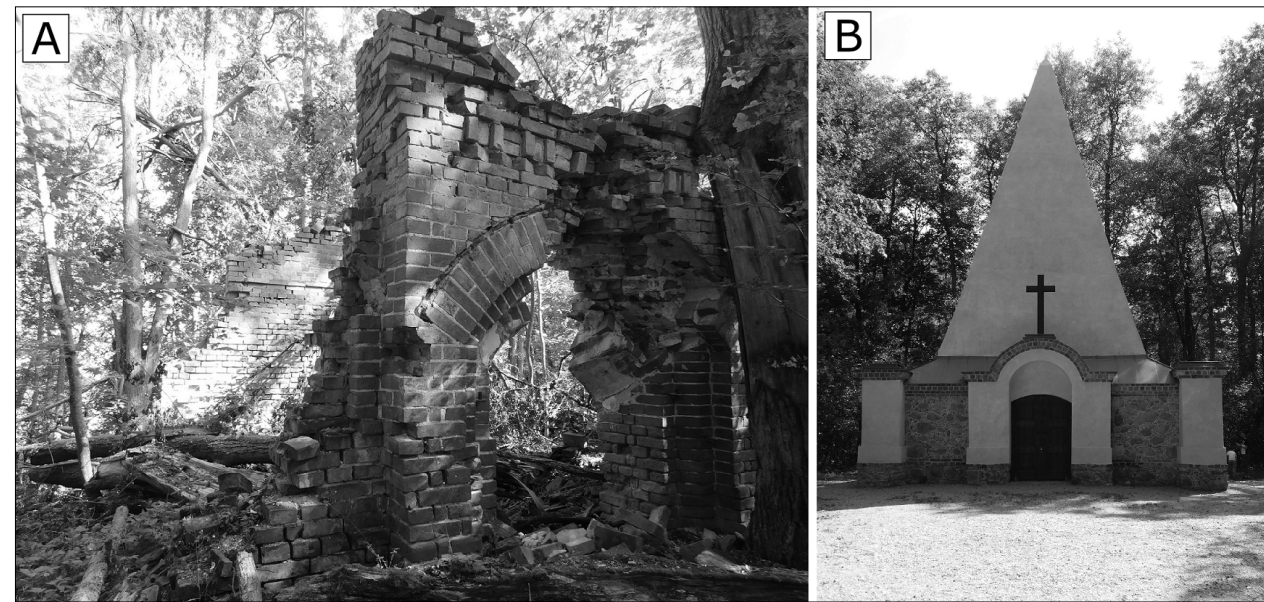

Ryc. 1. Przykłady prywatnych miejsc pochówku: A) ruiny kaplicy grobowej / mauzoleum rodowego koto Suchodotów w powiecie kętrzyńskim, B) grobowiec Fahrenheidów w Rapie (fot. A. Majewska, 2019)

na poświęconej ziemi ${ }^{18}$. Miejsca pochów$\mathrm{ku}$ organizowano więc również $\mathrm{w}$ małych wsiach i osadach, zwłaszcza jeśli dzieliła je znaczna odległość od centrum parafii. Popularne były jednak również mogilniki prywatne, zakładane przy dworach czy leśniczówkach. Chowano na nich zazwyczaj członków jednej bądź kilku spokrewnionych ze sobą rodzin, stąd określa się je mianem cmentarzy rodowych. Nie bez znaczenia była tu chęć podkreślenia swojej pozycji społecznej i przynależności do określonej grupy. Aby to zrozumieć, należy przywołać niuanse dziewiętnastowiecznej mazurskiej mentalności. Przybliża je ks. Krzysztof Bielawny, objaśniając podział na gburów, czyli bogatych chłopów, oraz tych biedniejszych i fornali ${ }^{19}$. Gdy tylko była taka możliwość, zamożniejsi organizowali prywatne cmentarze. Mogilniki przy dworach podkreślały pozycję danego wschodniopruskiego rodu, niekiedy wywodzącego się z arystokracji (m.in. rodów junkierskich). Przykładami są tu cmentarze rodzin Kullacków-Ublicków w Ubliku, Dohnów koło Markowa, mogilnik

\footnotetext{
${ }^{18}$ A. Rydzewska, Zabytkowe cmentarze ewangelickie pótnocnej Wielkopolski, Poznań 2012, s. 64; T. Żurkowska, Warto odwiedzić mazurskie cmentarzyki, "Znad Pisy", 12, 2003, s. 276

${ }^{19}$ K. Bielawny, Nekropolie, s. 162.
}

z kaplicą grobową Lehndorfów w Sztynorcie i piramidalny grobowiec Fahrenheidów w Rapie (ryc. 1). Tam, gdzie przestrzeń cmentarza współużytkowały różne grupy, podobnie jak w życiu codziennym zaznaczały się podziały społeczne. Wydzielano więc osobne kwatery, a zamożniejsi wygradzali miejsca pochówku swoich krewnych kutymi ogrodzeniami żeliwnymi, podkreślając istniejące rozwarstwienie fizycznie, ale i symbolicznie ${ }^{20}$. Podobną rolę pełniły kaplice grobowe oraz kwatery, tworzone niekiedy na specjalnie usypanych ziemnych platformach ${ }^{21}$.

Niewykluczone, że wpływ na lokowanie cmentarzy w miejscowościach poza ośrodkami kościelnymi i upowszechnienie się tego zwyczaju miały również lokalne pomory. W nowożytności szczególnie intensywnie dotknęły one mazurskie społeczności na początku XVIII w., gdy zdziesiątkowała je epidemia dżumy ${ }^{22}$.

\footnotetext{
${ }^{20}$ Por. T. Żurkowska, Mazurskie cmentarze, s. 23.

${ }^{21} 0$ platformach ziemnych na cmentarzach w osadach fryderycjańskich zob. M. Cepil, Śladami osadników fryderycjańskich w środkowej Polsce. Cmentarze i ich pozostałości, ,„Studia z Geografii Politycznej i Historycznej”, 6, 2017, s. 213.

22 S. Flis, Dżuma na Mazurach i Warmii w latach 1708-1711, „Komunikaty Mazursko-Warmińskie", 4, 1960, s. 473-523; A. Majewska, Zanikłe osadnictwo w granicach powiatu piskiego, tódź 2018, mps pracy magisterskiej, Uniwersytet Łódzki, s. 55-59.
} 
Popularność organizowania cmentarzy w wiejskich jednostkach osadniczych miała znaczący wpływ na oblicze fizycznego krajobrazu Prus Wschodnich. Pomimo upływu dziesięcioleci i postępującej degradacji nadal są one jednymi $\mathrm{z}$ najbardziej rozpoznawalnych elementów krajobrazu kulturowego i symbolami dawnych protestanckich Prus. W poszczególnych powiatach znajdują się ich setki, zwłaszcza we wschodniej i południowej (mazurskiej) części dawnej niemieckiej prowincji. Na terenie samego tylko powiatu piskiego (daw. Kreis Johannisburg) funkcjonowały przed $1945 \mathrm{r}$. 274 wiejskie i prywatne cmentarze ${ }^{23}$. $Z$ różnych przyczyn jednak, często niemożliwych dziś do ustalenia $\mathrm{z}$ uwagi na brak przekazów pisanych, nie w każdej miejscowości wydzielano teren do grzebania zmarłych.

Cmentarze znajdowały się w 149, czyli 19 proc. wszystkich wyludnionych obecnie jednostek osadniczych na obszarze badań (ryc. 2A, 2B). Nie można się więc zgodzić $\mathrm{z}$ powtarzanymi dotychczas $\mathrm{w}$ literaturze stwierdzeniami, jakoby mogilniki zakładane były przy każdej mazurskiej wsi, przysiółku czy majątku ${ }^{24}$. Najwięcej miejsc pochówku (85) przynależało do wielozagrodowych jednostek osadniczych, głównie typu wsi i osad (cmentarze znajdowały się w 42,5 proc. wszystkich obecnie wyludnionych miejscowości wielozagrodowych) (ryc. 2C). Kolejne 34 wchodziły w skład założeń dworskich (21 proc. wszystkich opuszczonych założeń) (ryc. 2D). W przypadku innych typów niezamieszkanych obecnie miejscowości mogilniki były znacznie rzadsze. Znajdowały się również m.in. przy 12 założeniach folwarcznych (10 proc. ogółu opuszczonych folwarków) i 8 leśniczówkach ( 9 proc. ogółu wyludnionych leśniczówek) (zob. ryc. 2E, 2F).

Większość mogilników wyludnionych wiejskich jednostek osadniczych położona

\footnotetext{
${ }^{23}$ Liczba oszacowana przez autorkę na podstawie analizy treści arkuszy mapy Topographische Karte Messtischblattz z lat dwudziestych-czterdziestych XX w. ${ }^{24} \mathrm{~Np}$. T. Zurkowska, Roślinność opuszczonych mazurskich cmentarzy, jej bogactwo i symbolika, w: Nekropolie Warmii i Mazur, s. 199.
}

jest we wschodniej części włączonych do Polski ziem wschodniopruskich (zob. porównanie do rozkładu przestrzennego wszystkich wyludnionych wiejskich jednostek osadniczych na ryc. 2). Jest to przede wszystkim teren Mazur, w zasięgu których znajdują się 103 wyludnione miejscowości mające cmentarze, co stanowi aż 69 proc. wszystkich miejsc pochówku zidentyfikowanych w toku przeprowadzonej analizy (zob. ryc. 2). Szczególnie dużo obiektów znajduje się przy wyludnionych osadach leśnych, zwłaszcza na obszarze Puszczy Piskiej. Zakładaniu osobnych mogilników sprzyjała tam dość rzadka sieć parafialna ${ }^{25}$. Duże odległości od śródleśnych osad do cmentarzy przykościelnych oraz kiepskiej jakości drogi, często nieutwardzone, były znaczącymi ograniczeniami dla prowadzenia konduktów pogrzebowych na przykład w czasie mroźnych i śnieżnych zim. $Z$ tego względu małe lokalne społeczności decydowały się na zakładanie własnych mogilników. Niewielkie cmentarze przy wiejskich jednostkach osadniczych były więc w dawnych Prusach Wschodnich elementami krajobrazu kulturowego charakterystycznymi w szczególności dla osad położonych wśród leśnych i jeziornych terenów Mazur. Z rzadka zaś można je było spotkać na Warmii i Żuławach, zamieszkiwanych dawniej również przez ludność o odrębnej tożsamości regionalnej i mającej nieco inne zwyczaje pogrzebowe (m.in. osadników olęderskich).

\section{b) Pamięć krajobrazu: położenie obiektów w środowisku geograficznym}

Cmentarze jako struktury wielowarstwo$w^{26}$ są niezwykle ważnymi ogniwami materialnej pamięci krajobrazu, stanowią

\footnotetext{
${ }^{25}$ Czynnik ten podkreśla również Krzysztof Bielawny, dodając jeszcze, że sytuowanie cmentarzy poza ośrodkami parafialnymi stanowiło sposób na unikanie wysokich opłat narzucanych za dokonywanie pochówków na cmentarzach przykościelnych. K. Bielawny, Nekropolie.

${ }^{26}$ Wielowarstwowość cmentarza wyznaniowego polega nie tylko na bogactwie wielowymiarowego przekazu kulturowego - materialnego i niematerialnego (warstwy semiotycznej). W sposób szczególny dotyczy też fizycznego krajobrazu cmentarza, stanowiącego rodzaj palimpsestu, na który składają się
} 

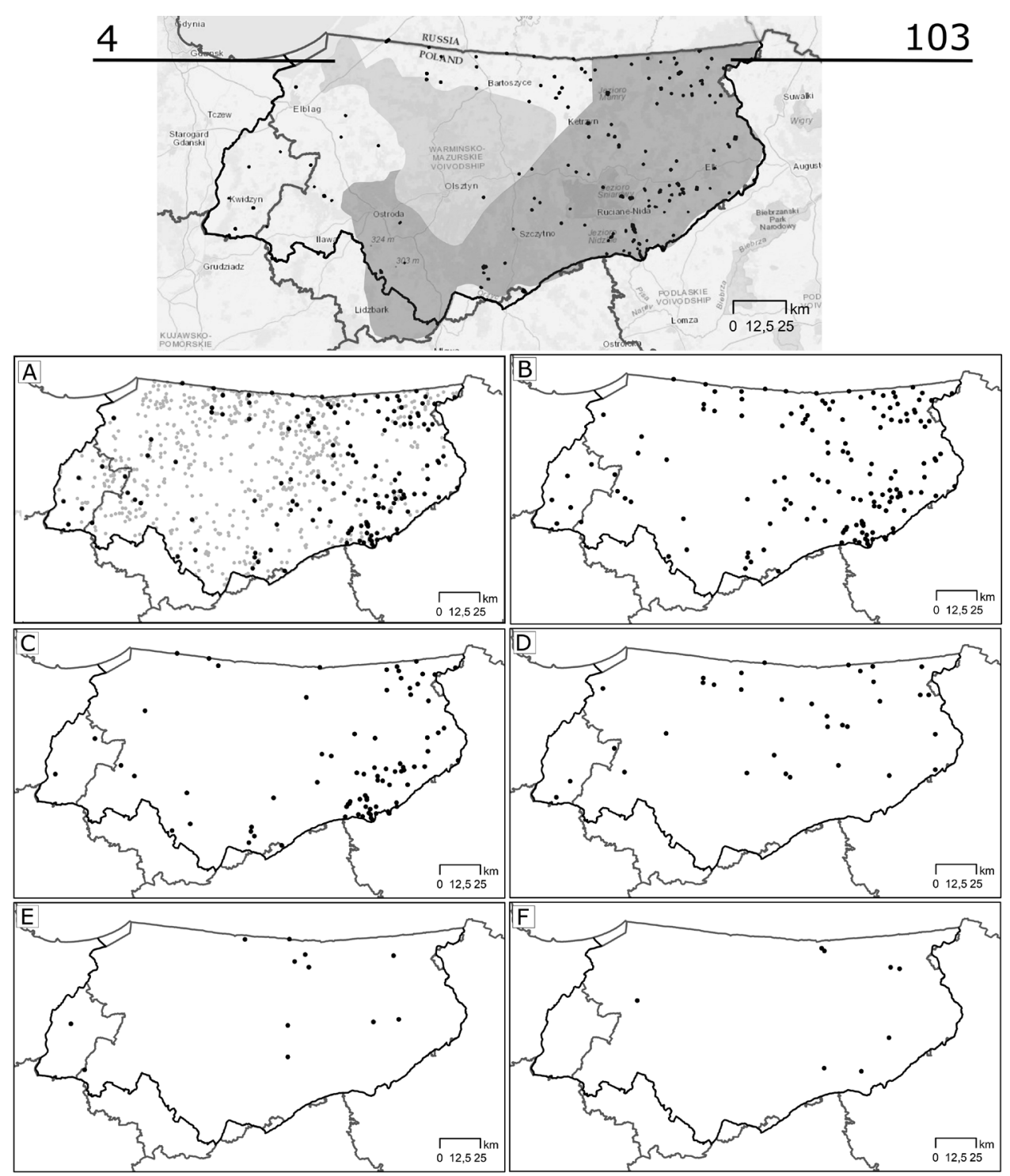

Ryc. 2. Wyludnione miejscowości mające odrębne cmentarze: A) ogótem na tle wszystkich opuszczonych miejscowości, B) opuszczone miejscowości z cmentarzami ogótem, C) miejscowości wielozagrodowe, D) założenia dworskie, E) założenia folwarczne, F) leśniczówki.

Źródto: oprac. własne

bowiem świadectwo o życiu lokalnych społeczności ${ }^{27}$. Informacje na temat funkcjonowania wspólnot w przeszłości

elementy pochodzące z różnych etapów jego funkcjonowania w przestrzeni. Więcej zob. A. Majewska, Surface prospection of burial grounds and new research tools (on the example of the study of changes in cemetery boundaries), , Journal of Geography, Politics and Society”, 7 (1), 2017, s. $65-68$.

${ }^{27}$ P. Ariès, The hour of our death, Harmondsworth 1983, s. 503. zostały zakodowane w ich nagrobkach, kwaterach i szacie roślinnej. Nie mniej istotne jest miejsce cmentarzy w przestrzeni geograficznej, a więc ich usytuowanie wobec siedlisk, obiektów fizjograficznych i form rzeźby terenu ${ }^{28}$,

${ }^{28}$ W zależności od kontekstu umiejscowienie cmentarzy w przestrzeni może stanowić przedmiot badań przedstawicieli nauk humanistycznych lub 
stanowiące składnik tejże nieludzkiej pamięci. Położenie obiektów zdeterminowane zostało uwarunkowaniami społeczno-kulturowymi i przestrzennymi ${ }^{29}$. O wielu z nich wnioskować można na podstawie obserwacji struktur krajobrazowych.

Analiza 147 przypadków lokalizacji cmentarzy względem obiektów fizjograficznych pozwoliła zaobserwować, że dominowała tendencja do organizowania miejsc pochówku w rejonach wyniesionych względem otoczenia i siedlisk. Zdecydowanie przeważa położenie na wyniesieniach terenu - zarówno w obrębie stoków, jak i w częściach szczytowych lokalnych wyizolowanych wzniesień (zob. ryc. 5). Tego rodzaju lokalizacjom sprzyjała rzeźba młodoglacjalna, bogata w liczne formy pagórkowate, m.in. wzniesienia morenowe $^{30}$ i kemy, których gleby, przeważnie nienadające się pod uprawy, przeznaczane były m.in. na lokalne mogilniki. Piaski i mułki warstwowo budujące kemy ${ }^{31}$ stanowiły podłoże ułatwiające dokonywanie pochówków. W aspekcie kulturowym położenie cmentarza na wzgórzu tworzyło związek między dwoma wymiarami istnienia: doczesnym - materialnym oraz pośmiertnym - duchowym, gdyż ci, którzy odeszli, mogli niejako spoglądać w kierunku zamieszkiwanych za życia zagród ${ }^{32}$. Anna Majdecka-Strzeżek dodaje, że takie miejsca zapewniały rozległe powiązania widokowe i „umożliwiały kontemplację piękna otaczającej przyrody", spełniając ponadto funkcję atrakcyjnych punktów obserwacyjnych $^{33}$. Współcześnie mogilniki usytuowane na wyniesieniach są nie tylko pamiątkami historycznego osadnictwa, ale

przyrodniczych, przede wszystkim geografów, archeologów, architektów krajobrazu i historyków. Por. M. Zawiła, Dziedziczynienie, s. 33-34.

${ }^{29}$ A. Długozima, Fenomen, s. 19.

${ }^{30}$ Tamże, S. 23

${ }^{31}$ P. Migoń, Geomorfologia, Warszawa 2006, s. 324.

${ }^{32}$ Por. T. Zurkowska, Mazurskie cmentarze, s. 11. Uzewnętrznia się tu również archetypiczna symbolika wzgórza jako miejsca znajdującego się bliżej Boga, zawieszonego między niebem a ziemią, paraleli ludzkiego życia.

${ }^{33}$ A. Majdecka-Strzeżek, Ogrody wiecznej pamięci w krajobrazie kulturowym, „Kwartalnik Architektury i Urbanistyki PAN”, 61 (3), 2016, s. 32. wyróżnione wysoką zielenią (szczególnie na otwartej przestrzeni), stanowią odrębne płaty w strukturze krajobrazu ${ }^{34} \mathrm{i}$ wyspy ekologiczne ${ }^{35}$.

W wielu przypadkach naturalne, pozytywowe formy rzeźby terenu podkreślano dodatkowo, kształtując sztuczne platformy i nasypy ziemne. Nadawane im były m.in. regularne owalne narysy kopców, jak w przypadku cmentarza przy dawnym folwarku Georgenhof (wys. względna obiektu: 3,37 m) (ryc. 3), bądź czworoboczne jak mogilnik przy wyludnionym założeniu dworskim Wallen (wys. względna obiektu: 2,72 m) (ryc. 4). Celowe kształtowanie form terenowych pod założenia cmentarne dotyczyło niemal wyłącznie niewielkich mogilników prywatnych. W większych założeniach działania ingerujące w ukształtowanie terenu ograniczane były do wytyczania wałów i rowów okalających cmentarze.

W przyjętej próbie badawczej zaobserwowano również częstsze lokalizowanie na stokach bądź wzniesieniach cmentarzy należących do założeń jednodworczych (szczególnie dworów) niż wielozagrodowych jednostek osadniczych. W przypadku tych drugich równie często organizowano je w terenie o nieznacznych deniwelacjach (zob. ryc. 5). Być może w przypadku ludniejszych miejscowości na wybór lokalizacji w większym stopniu wpływały dogodne połączenie komunikacyjne $\mathrm{z}$ cmentarzem oraz możliwość korzystniejszego rozplanowania kwater, dlatego nie wybierano mniej dostępnych szczytów wzniesień, gdzie powierzchnię grzebalną ograniczały krawędzie stoków. Znacznie trudniej było rozplanować na wzgórzu cmentarz o większej powierzchni (powyżej 1 tys. $\mathrm{m}^{2}$ ) i w regularnych granicach ${ }^{36}$.

Analizując usytuowanie cmentarzy przynależących do wyludnionych miejscowości

\footnotetext{
${ }^{34}$ A. Majewska, Depopulated localities, s. $42-50$.

${ }^{35}$ A. Rydzewska, Zabytkowe cmentarze, s. 64.

${ }^{36}$ Agnieszka Rydzewska, przytaczając zasady organizacji przestrzennej cmentarzy ewangelickich, podaje, że rozplanowanie powinno mieć charakter równomierny i symetryczny. Tamże, s. 15.
} 

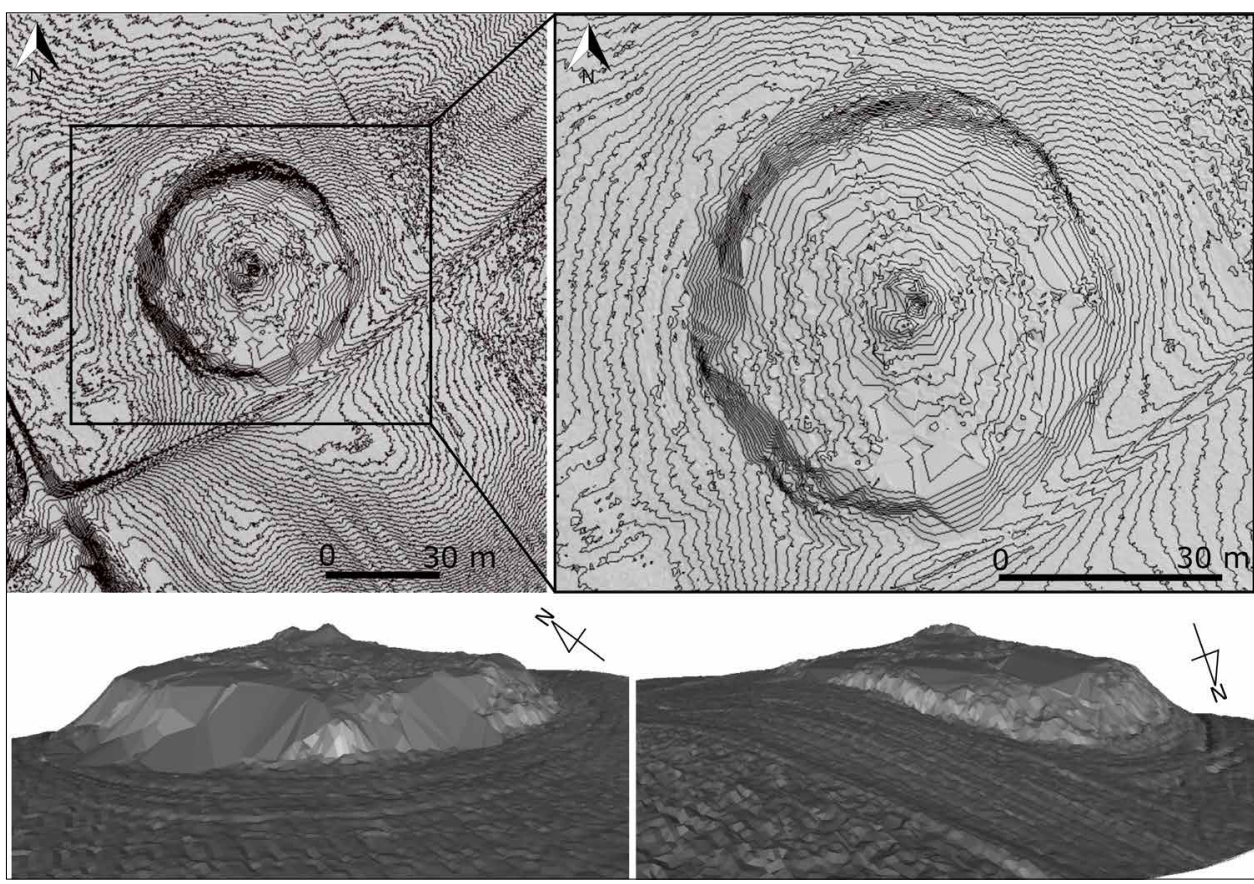

Ryc. 3. Cmentarz przy opuszczonym założeniu dworskim Georgenhof w powiecie sztumskim: mapa warstwicowa (cięcie poziomicowe: 0,15 m) oraz model 3D uksztattowania powierzchni gruntu. Źródto: oprac. własne na podstawie danych chmury punktów z zasobów GUGiK, ark. N-34-75-A-c-2-3-2

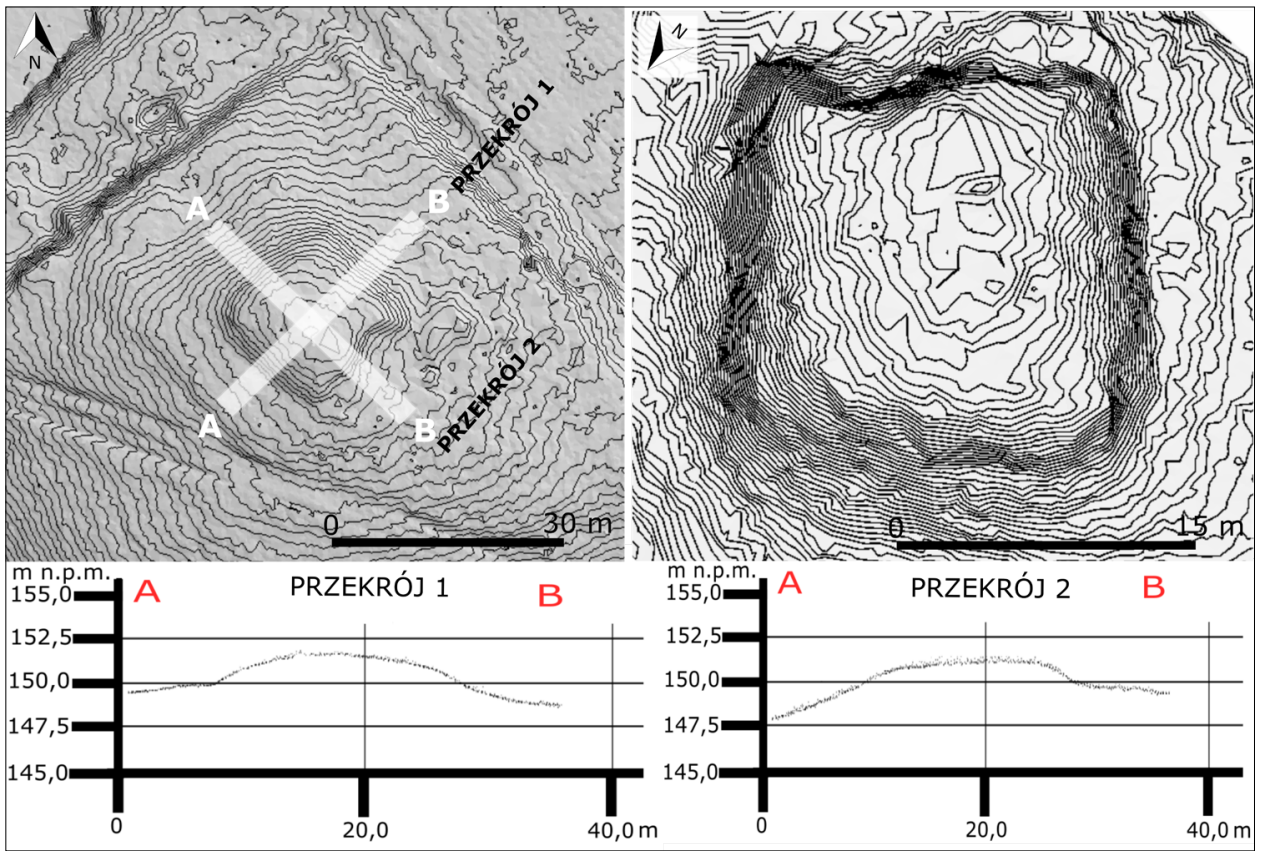

Ryc. 4. Cmentarz przy opuszczonym założeniu dworskim Wallen w powiecie olsztyńskim: mapa warstwicowa (cięcie poziomicowe: 0,10 m) oraz przekroje wysokościowe przez obiekt (szer. przekroju: $2 \mathrm{~m}$, dt.: $35 \mathrm{~m}$ ). Źródto: oprac. własne na podstawie danych chmury punktów z zasobów GUGiK, ark. N-34-78-D-c-1-1-1 


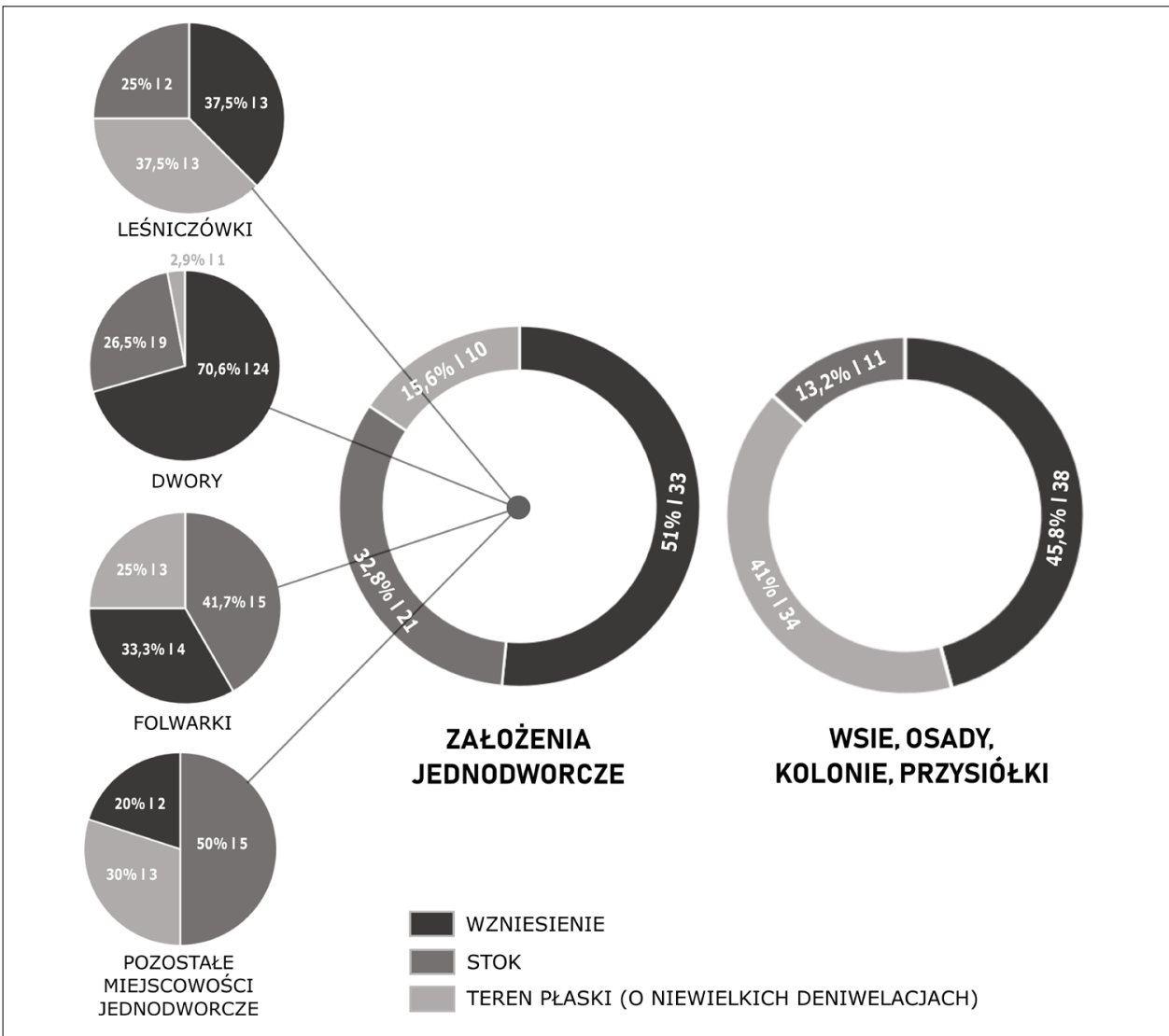

Ryc. 5. Położenie cmentarzy wyludnionych miejscowości pod względem ukształtowania terenu.

Źródło: oprac. własne

z obszaru badań na niemieckich mapach topograficznych wydawanych od końca XIX w. do lat czterdziestych stulecia XX, można zauważyć, że często zlokalizowane były na terenach leśnych. Poza warunkami położenia samych jednostek osadniczych (choćby w przypadku leśniczówek) do najczęstszych przyczyn sytuowania obiektów grzebalnych w lasach należą czynniki kulturowe, w tym walory estetyczne i symboliczne. Na terenie Mazur już w czasach pogańskich występował zwyczaj grzebania zmarłych w lasach, a wśród Prusów - jak podaje Sławomir Wadyl - praktykowane było to jeszcze w XV w. ${ }^{37}$ Gdy tereny te

\footnotetext{
${ }^{37}$ S. Wadyl, Niektóre elementy wyobrażeń religijnych Prusów i ich trwanie w czasach krzyżackich, „Komunikaty Mazursko-Warmińskie”, 2, 2010, s. 191.
}

zamieszkiwane były przez plemiona staropruskie, lasy stanowiły ważny element wierzeń - to bezpośrednio drzewa wiązano $z$ kultem, m.in. lipę i dą $b^{38}$. Symbolika tych drzew jako związanych z sacrum zakorzeniła się również w tradycji chrześcijańskiej ${ }^{39}$. Znaczenie miały zapewne również względy praktyczne, a mianowicie wykorzystywanie pod pochówki piaszczystych gleb występujących pod lasami iglastymi, których nie eksploatowano rolniczo. Grzebanie zmarłych w lasach sosnowych nie sprawiało trudności ze względu na nierozbudowany palowy system korzeniowy tych drzew.

\footnotetext{
${ }^{38} \mathrm{G}$. Białuński, W sprawie lasów i leśnictwa w południowo-wschodnich Mazurach od XIV do początku XVIII wieku, „Komunikaty Mazursko-Warmińskie", 3, 1996, s. 434.

${ }^{39}$ A. Majdecka-Strzeżek, Ogrody, s. 26.
} 

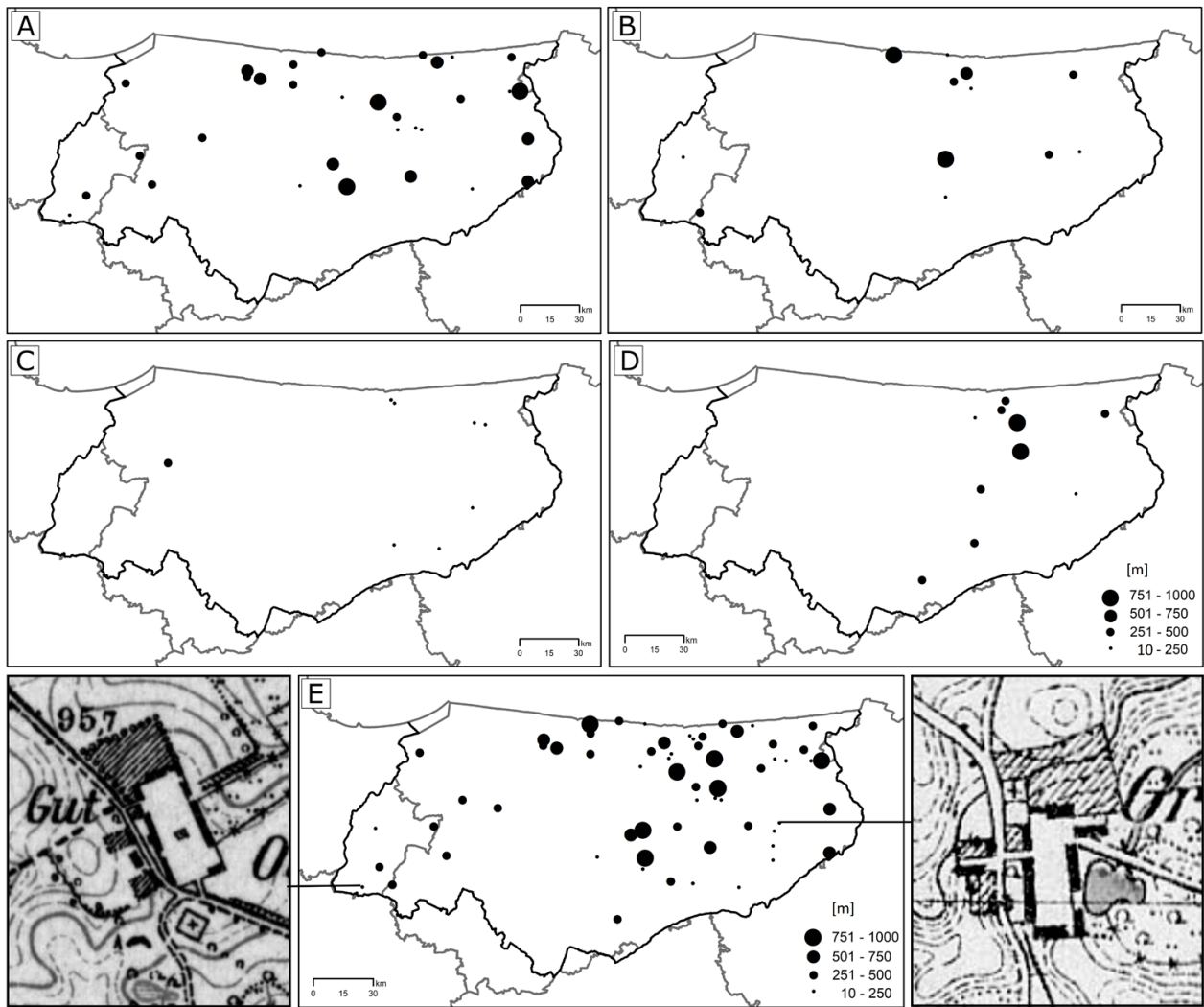

Ryc. 6. Odlegtość cmentarzy od dawnych zabudowań wyludnionych obecnie miejscowości jednodworczych: A) założeń dworskich, B) założeń folwarcznych, C) leśniczówek, D) pozostatych miejscowości jednozagrodowych; E) zestawienie zbiorcze z przykładami założeń z najmniejszą odległością od cmentarzy $(<50 \mathrm{~m})$.

Źródto: oprac. własne z wykorzystaniem fragmentów mapy „Topographische Karte”, ark. 2198: „Dippelsee”, 1938, ark. 2379: „Olschowken”, 1933

W przypadku osad położonych w pobliżu zbiorników bądź cieków cmentarze usytuowane są w miejscach powiązanych widokowo z obiektami hydrograficznymi - na nadjeziornej skarpie bądź terasie naddzalewowej (np. Spirdingswerder, Ulpitten, Broschaitschen, Klein Maradtken, Wondollen). Charakterystyczna dla takich lokalizacji jest orientacja nagrobków nie według kierunków geograficznych, ale w stronę obiektu wodnego, wyrażająca symboliczną ciągłość pomiędzy sacrum i profanum oraz przekonanie, że zmarli powinni mieć możliwość spoglądania na ukochany za życia krajobraz ${ }^{40}$.

${ }^{40}$ Por. A. Długozima, Fenomen, s. 33.
Odległość cmentarza od zabudowań ma z kolei większy związek z obostrzeniami sanitarnymi ${ }^{41}$ i kwestiami praktycznymi, choć nie pozostaje wolna od uwarunkowań kulturowych i tradycji. W grupie mających mogilniki wyludnionych miejscowości o charakterze jednodworczym średni dystans od zabudowań do cmentarza wynosił 374 m (mediana: $345 \mathrm{~m}$ ). W 70 proc. przypadków odległości do miejsc pochówku wynosity do $500 \mathrm{~m}$, a w 35 proc. - poniżej 250 m (zob. ryc. 6E). Spośród tego

${ }^{41}$ Od XIX w. cmentarze zaczęto wyprowadzać poza granice miejscowości. Zasada ta obowiązywała również w przypadku mogilników wiejskich, dlatego większość z nich przed drugą wojną światową dzielit wyraźny dystans od najbliższych zabudowań. Por. taż, Cmentarze jako ogrody żywych i umarlych, Warszawa 2011, s. 62-63, 66. 


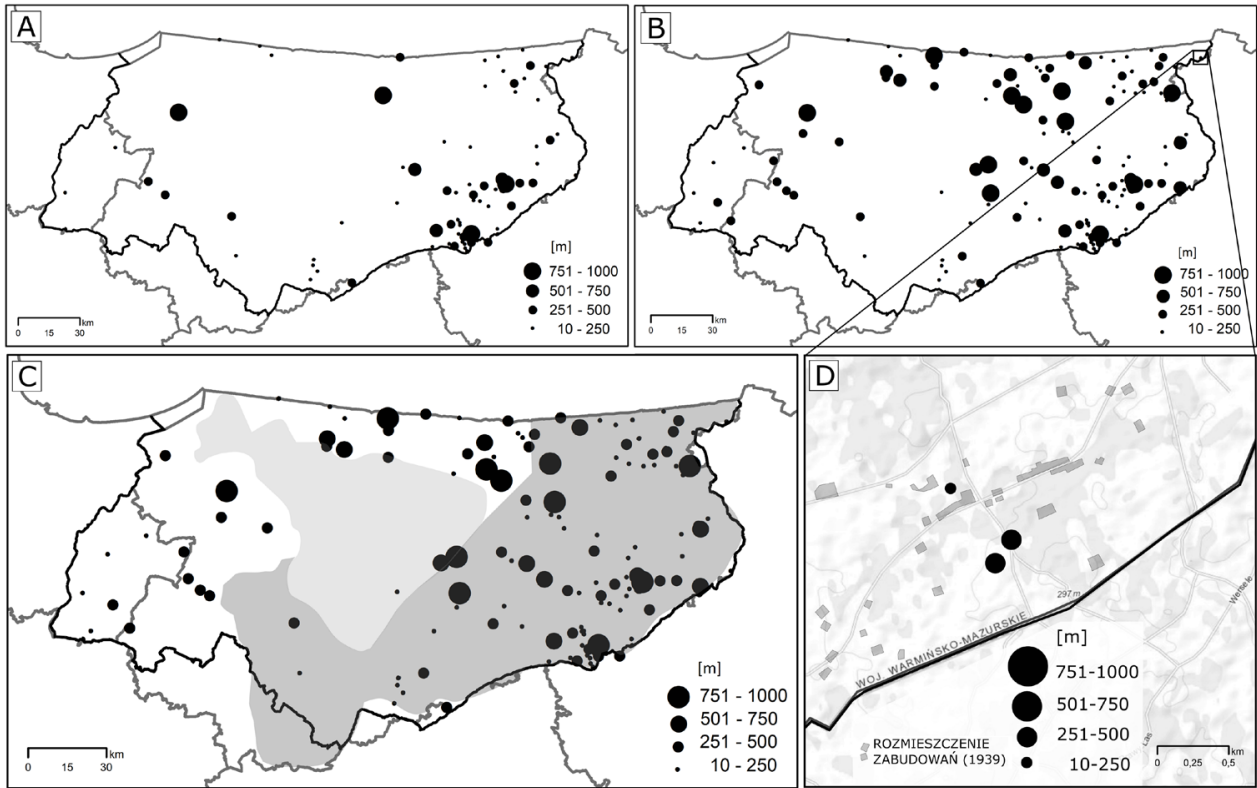

Ryc. 7. A) odległości cmentarzy od dawnych zabudowań wyludnionych obecnie wsi, osad, kolonii i przysiótków mających odrębne mogilniki; B) odległości od zabudowań dla wszystkich wyludnionych miejscowości mających odrębne cmentarze; C) odlegtości od zabudowań dla wszystkich wyludnionych miejscowości mających odrębne cmentarze z uwzględnieniem zasięgu głównych krain historyczno-geograficznych; D) przybliżenie miejscowości mającej 3 cmentarze (Unterfelde).

Źródło: oprac. własne

rodzaju osad mogilniki miało jednak tylko kilka: założono je w obrębie siedliska bądź w latach dwudziestych-czterdziestych XX w. znajdowały się w bardzo bliskiej odległości od zagród (do $50 \mathrm{~m}$ ). Było tak w przypadku 6 jednostek osadniczych: leśniczówki Sdrusno, folwarku Braktin, osady jednodworczej Grünthal oraz założeń dworskich: Klonn, Olschowken i Wallen ${ }^{42}$. Podobnie niewiele jest obiektów, które od siedliska miejscowości jednodworczej dzieliło więcej niż $750 \mathrm{~m}$ (w żadnym z nich nie była to jednak odległość większa niż $1 \mathrm{~km})$ - zidentyfikowano takich 7 .

W grupie wyludnionych obecnie dawnych miejscowości wielozagrodowych (wsi, osad, kolonii i przysiółków) podobnie jak

\footnotetext{
${ }^{42}$ Ponieważ analiza odległości została przeprowadzona w oparciu o dane archiwalnych map topograficznych, nie można wykluczyć istnienia większej liczby cmentarzy zlokalizowanych bezpośrednio przy zabudowaniach. Przykładowo zidentyfikowany podczas prospekcji terenowej pochówek na terenie dawnego dworu Bartkenhof w powiecie oleckim nie był oznaczony na mapach topograficznych.
}

w przypadku założeń jednodworczych niewiele cmentarzy znajdowało się w obrębie niwy siedliskowej - tylko $14 \mathrm{z} 83$. W odległości do $50 \mathrm{~m}$ od zabudowań usytuowanych było ich 20 (24 proc.), a do $500 \mathrm{~m}-75$ (aż 91 proc.) (ryc. 7A). Średni dystans oraz mediana odległości od miejsc pochówku do najbliższych budynków miały tu mniejsze wartości niż w przypadku założeń jednodworczych, wynosząc odpowiednio 237 i $185 \mathrm{~m}$ (zob. ryc. 8).

W odróżnieniu od założeń jednodworczych we wsiach i osadach postępujący rozwój przestrzenny mógł prowadzić do skracania odległości od istniejących miejsc pochówku (przykładem jest utworzona w sąsiedztwie cmentarza kolonia miejscowości Robitten). Dane dotyczące miejscowości o charakterze jednodworczym wykazują, że im mniejsza była jednostka osadnicza, tym mniejszy dystans dzielił zabudowania i cmentarz (zob. ryc. 8). Było 


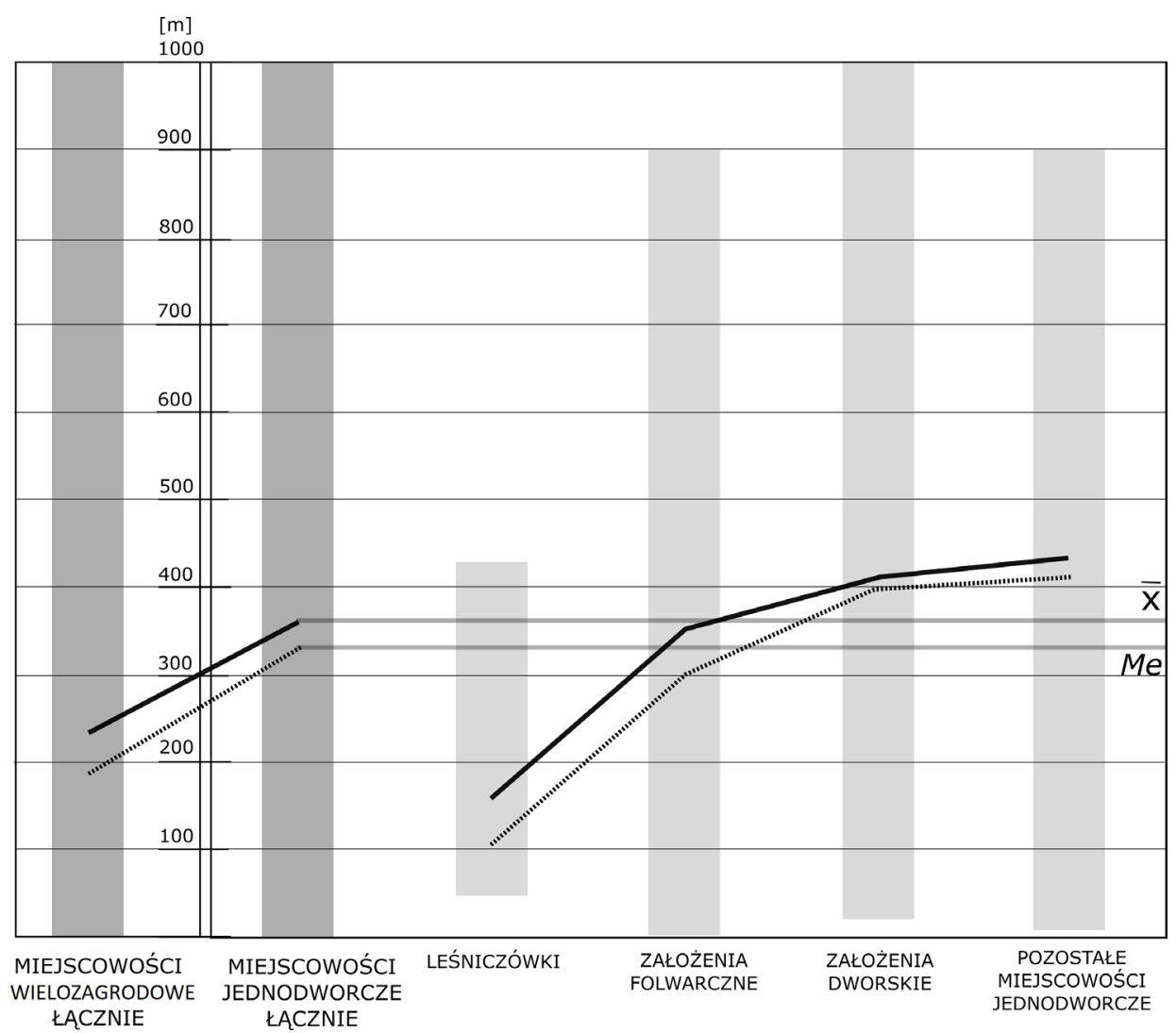

Ryc. 8. Odlegtości od cmentarzy do najbliższych zabudowań wyludnionych obecnie miejscowości wg stanu

$z$ lat dwudziestych-czterdziestych XX w.

$\bar{X}$-średnia; Me - mediana.

Źródto: oprac. własne

to podyktowane m.in. powierzchnią wiejskich rozłogów bądź parceli przynależących do danej osady, w tym określonego przeznaczenia. Tym samym grupą o najmniejszej średniej odległości siedlisk od cmentarzy prywatnych są leśniczówki ${ }^{43}$ : 7 z $8^{44}<250 \mathrm{~m}$ (przykłady zob. ryc. 9). Większe wartości dotyczą kolejno założeń folwarcznych i dworskich (ryc. 8).

Lokalizacje cmentarzy wobec siedlisk zależały również od morfogenetycznego

\footnotetext{
${ }^{43}$ Leśniczówki są bardzo specyficzną grupą wśród wyludnionych wiejskich jednostek osadniczych. Otoczone terenami zalesionymi, miały wydzielone małe działki siedliskowe oraz parcele przeznaczone na użytek gospodarczy. Możliwości sytuowania prywatnych miejsc pochówku były w związku z tym bardzo ograniczone przestrzennie.

${ }^{44}$ Są to dawne leśniczówki: F. Birkenbruch, F. Elterholz, F. Hartwichs, F. Nordenort, F. Sdrusno (Eichborn), F. Seehof, F. Wiersbianken, F. Wolfshagen.
}

typu jednostek osadniczych ${ }^{45}$. Wśród wyludnionych miejscowości obszaru badań szczególnie częste były wymieniane przez Stanisława Srokowskiego mazurskie osady wielodrożne oraz wsie ulicowe, występujące jako odmiana wsi drogowej ${ }^{46}$. Tego typu miejscowości rozciągały się najczęściej wzdłuż jeziornego brzegu lub głównej drogi prowadzącej przez osadę ${ }^{47}$. Wsie warmińskie to z kolei przede wszystkim ulicówki, owalnice, osady placowe

${ }^{45}$ Zob. A. Długozima, Fenomen, s. 31.

${ }^{46}$ S. Srokowski, Prusy Wschodnie. Kraj i ludzie, Warszawa 1929, s. 33-34; H. Szulc, Morfogenetyczne typy osiedli wiejskich na Pomorzu Zachodnim, Warszawa 1988, s. 32.

${ }^{47}$ B. Zalewska, Klon: przyczynek do problematyki ochrony układów ruralistycznych województwa warmińsko-mazurskiego, „Rocznik Mazurski”, 6, 2002, s. 117. 


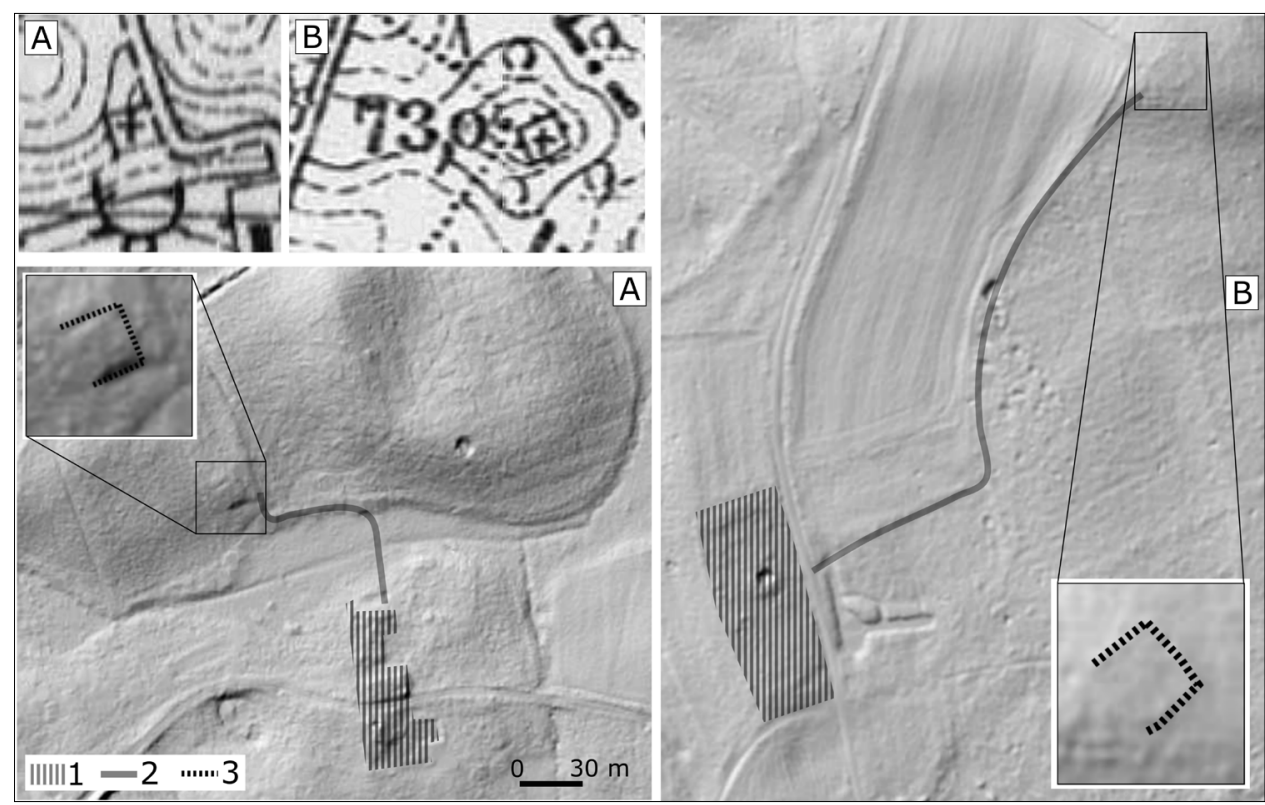

Ryc. 9. Cmentarze przy wyludnionych leśniczówkach: przykłady lokalizacji i reliktów granic mających własne formy terenowe: A) F. Elterholz, B) F. Wolfshagen.

1. siedlisko miejscowości, 2. droga prowadząca do cmentarza, 3. czytelne odcinki granic cmentarza.

Źródto: oprac. własne z wykorzystaniem materiatów NMT z cieniowaniem: „Geoportal Infrastruktury Informacji

Przestrzennej" (www.geoportal.gov.pl, dostęp: 6 stycznia 2019) oraz fragmentów „Topographische Karte”, ark. 1898:

„Kerschken”, 1938, ark. 1794: „Barten”, 1937

i folwarczne oraz rozproszone samotnicze zagrody ${ }^{48}$. Cmentarze znajdujące się w niewielkiej odległości od zabudowań położone były zatem przy głównych drogach, często na skrzyżowaniach - rozstajach dróg, co miało podłoże w ludowych przesądach wywodzących się jeszcze z okresu wczesnonowożytnego. Według tradycji grzebanie zmarłych $\mathrm{w}$ takim miejscu zapobiegało powrotom dusz do wsi i niepokojeniu żyjących ${ }^{49}$. W miejscowościach mających centralny plac cmentarz organizowano niekiedy w jego obrębie. Sytuowanie

\footnotetext{
${ }^{48}$ M.A. Fenyk, K. Kuszewska, Flora opuszczonych sadyb gospodarskich Warmii, „Acta Scientarium Polonorum”, 9 (2), 2010, s. 60, za: W. Łaguna, Sieć osadnicza Ziemi Warmińskiej - geneza i ewolucja do stanu obecnego, w: Społeczeństwo, środowisko, gospodarka i krajobraz kulturowy Warmii w roku Ignacego Krasickiego, Olsztyn-Lidzbark Warmiński 2001.

${ }^{49}$ Zob. P. Duma, Grób alienata. Pochówki dzieci nieochrzczonych, samobóiców iskazańców w późnym średniowieczu i dobie wczesnonowożytnej, Kraków 2010. Podobna, izolacyjna role spełniało sadzenie kolczastych krzewów wzdłuż granic cmentarzy. Zob. T. Żurkowska, Mazurskie cmentarze, s. 26.
}

mogilników $\mathrm{w}$ otoczeniu zagród było jednak praktyką stosunkowo rzadką, choć w wielu miejscowościach zachowany był jedynie niewielki dystans do najbliższych zabudowań, a do cmentarzy położonych na granicy siedlisk i pól prowadzity wąskie nieutwardzone drogi. Na tym tle lokalizacją wyróżniają się zwłaszcza cmentarze rodowe, zakładane przy dworach i folwarkach. Ich usytuowanie zazwyczaj ściśle wpisuje się w układ kompozycyjny całego założenia $^{50}$. Aleje prowadzące do takich mogilników obsadzane były drzewami, co niewątpliwie miało wymiar symboliczny ${ }^{51}$.

$\mathrm{Na}$ podstawie analizy lokalizacji 147 cmentarzy z niezamieszkanych jednostek osadniczych wyróżniono podstawowe typy ich położenia względem dawnych przestrzeni zamieszkiwania - niw siedliskowych

\footnotetext{
${ }^{50}$ Zob. taż, Roślinność, s. 200.

${ }^{51}$ Zob. A. Długozima, Fenomen, s. 37.
} 


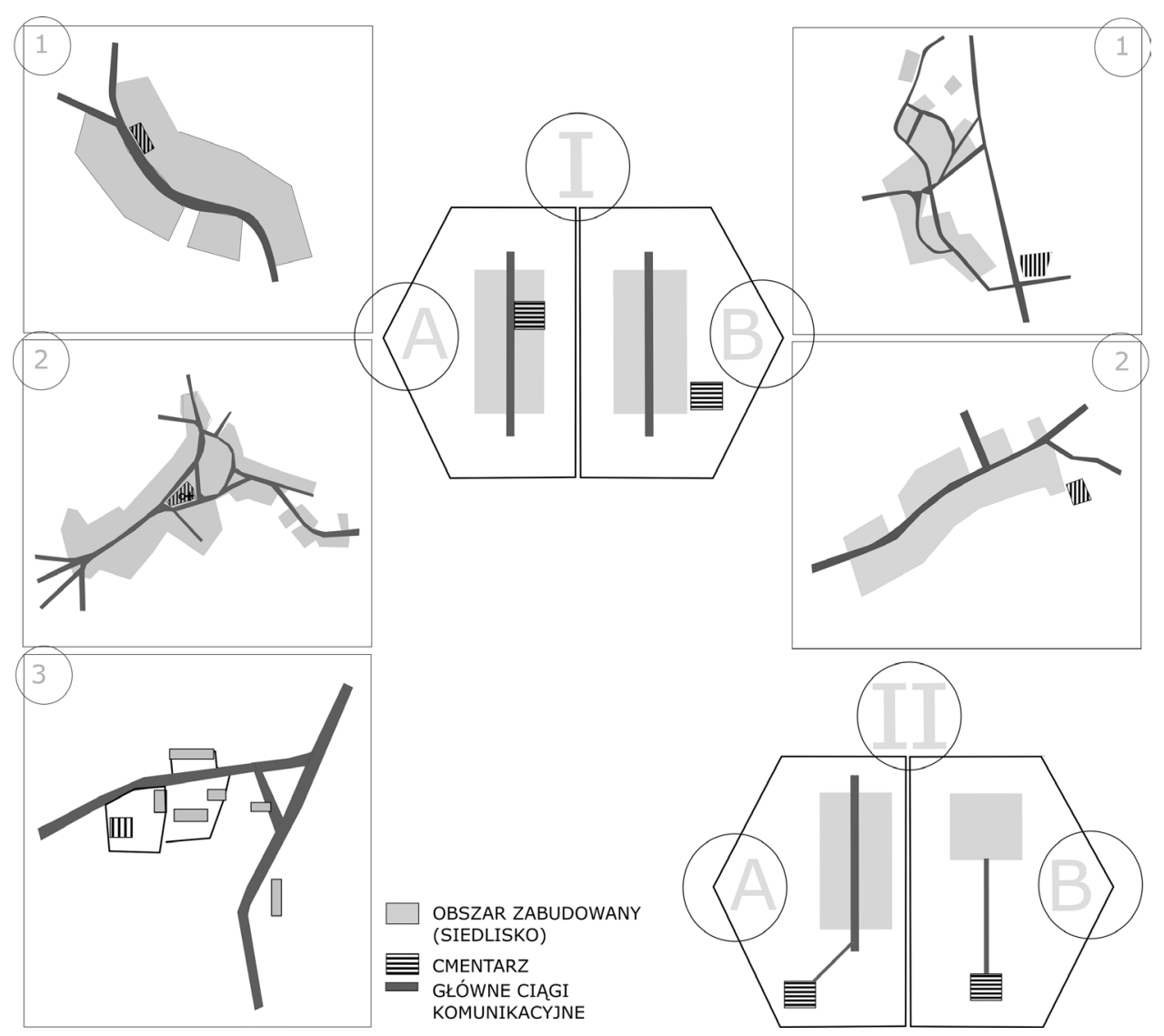

Ryc. 10. Podstawowe typy usytuowania cmentarzy względem siedlisk wyludnionych miejscowości w polskiej części dawnych Prus Wschodnich.

Źródto: oprac. własne

oraz innych wybranych morfologicznych elementów jednostek osadniczych ${ }^{52}$ :

I. Brak odstępu bądź niewielka odległość od cmentarza do zabudowań:

1. umiejscowienie cmentarza w obrębie siedliska:

a) pomiędzy zagrodami (np. Heidensee, Hammergehsen i Prziroscheln),

b) na terenie placu przykościelnego oraz/lub nawsia (np. Małga),

c) na terenie założenia parkowo-ogrodowego w sąsiedztwie budynku

\footnotetext{
${ }^{52}$ Typy położenia cmentarzy wobec niw siedliskowych dotyczą relacji przestrzennych zachodzących w latach dwudziestych-czterdziestych XX w., kiedy badane miejscowości były zamieszkanymi jednostkami osadniczymi.
}

mieszkalnego (np. Barkenhof i Steinau);

2. umiejscowienie cmentarza na granicy z siedliskiem:

a) przy głównej drodze bądź na rozstaju dróg (np. Orschen, Puchallowen i Schast),

b) na terenie użytków rolnych, obszarów leśnych bądź użytkowanych gospodarczo i w sąsiedztwie zabudowań (np. Valenzinnen, Waldenfried i Stürmersberg).

II. Zachowany odstęp od cmentarza do zabudowań:

1. lokalizacja niepowiązana z układem przestrzennym miejscowości (np. Soldahnen i Fischborn); 
2. lokalizacja powiązana z układem przestrzennym miejscowości (np. na wyznaczonej aleją osi założenia dworskiego lub folwarcznego, jak w przypadku Groß Blandau) ${ }^{53}$.

\section{Podsumowanie}

Cmentarze wyludnionych miejscowości Warmii, Mazur i Powiśla stanowią galerie przeszłości ${ }^{54}$, naznaczone dramatycznymi wydarzeniami drugiej wojny światowej i okresu powojennego, w wyniku których z czynnych miejsc dokonywania pochówków stały się przeważnie zapomnianymi świadectwami życia lokalnych społeczności. Omówione w artykule zagadnienia dotyczące materialnej pamięci cmentarzy pokazują, jak wiele informacji o funkcjonowaniu dawnych wschodniopruskich wspólnot zakodowane zostało w ich strukturach oraz lokalizacji w środowisku geograficznym. Przyjęcie perspektywy badawczej zogniskowanej na materialnym trwaniu obiektów w krajobrazie zakłada nie tylko poznanie ich fizykalnej specyfiki;

\section{Bibliografia}

Archeologia wspótczesności. Pierwszy Kongres Archeologii Polskiej, t. 1, red. A.I. Zalewska, Warszawa 2016. Ariès P., The hour of our death, Harmondsworth 1983. Białuński G., W sprawie lasów i leśnictwa w potudniowo-wschodnich Mazurach od XIV do poczatku XVIII wieku, „Komunikaty Mazursko-Warmińskie”, 3, 1996.

Bielawny K., Nekropolie w granicach parafii ewangelickich Nawiady, Piecki i Stara Ukta przed 1945 rokiem, „Znad Pisy”, 15, 2006.

Burzyńska M., Miejsca nie-pamięci, „Menażeria” (http://menazeria.eu/8, przejazd.html?artykulID=168, dostęp: 8 lutego 2020).

\footnotetext{
${ }^{53}$ Bardziej szczegółowego omówienia lokalizacji cmentarzy rodowych pod względem powiązań widokowych dokonała Anna Majdecka-Strzeżek: A. Majdecka-Strzeżek, Ogrody, s. 32.

${ }^{54}$ Tak zabytkowe nekropolie określają historycy sttuki. J. Kołacki, Koncepcja badania cmentarzy protestanckich w Wielkopolsce. Studium przypadku Wolsztyn, w: Cmentarze nieistniejących cmentarzy. Ewangelickie dziedzictwo kulturowe w Wolsztynie (w 500. rocznicę reformacii), red. J. Kołacki, Poznań 2018, s. 60.
}

kwantyfikacja, generalizacja, a następnie interpretacja wyników badań przybliżają również wybrane kulturowe i społeczne aspekty dawnego i obecnego funkcjonowania cmentarzy w przestrzeni. Duże znaczenie ma również możliwość płynnego przechodzenia od analiz makroskalowych do mikroskalowych (dotyczących poszczególnych obiektów), na co pozwala wykorzystanie danych pomiarowych z lotniczego skanowania laserowego. Przybliżenie kontekstu przestrzennego oraz morfologicznych cech obiektów za pośrednictwem szczegółowych danych wysokościowych umożliwia określenie m.in. genezy poszczególnych form, a więc i sposobów organizacji miejsc grzebania zmarłych. Podlegające degradacji materialne ślady obserwowane w krajobrazie są często jedynymi i ostatnimi reliktami, za pośrednictwem których możemy dociekać o wydarzeniach i procesach oraz współuczestniczących w nich ludziach. Warto poświęcić im uwagę, nim całkowicie znikną.

Cepil M., Śladami osadników fryderycjańskich $w$ środkowej Polsce. Cmentarze i ich pozostatości, „Studia z Geografii Politycznej i Historycznej”, 6, 2017.

Cmentarze nieistniejacych cmentarzy. Ewangelickie dziedzictwo kulturowe $w$ Wolsztynie (w 500. rocznice reformacji), red. J. Kołacki, Poznań 2018.

Dethlefsen E.S., The cemetery and culture change. Archaeological focus and ethnographic perspective, w: Modern material culture and archaeology of us, ed. R.A. Gould, M.B. Schiffer, New York 1981.

Długozima A., Cmentarze jako ogrody żywch $i$ umartych, Warszawa 2011.

Długozima A., Fenomen cmentarzy warminskich $i$ mazurskich $w$ aspekcie ich potożenia $w$ krajobrazie, w: Nekropolie Warmii i Mazur, red. W. Knercer, B. Wacławik, Olsztyn 2016.

Domańska E., Cmentarze jako przedmiot historii ratowniczej (rescue history), w: „Ziemia skrywa kości”. Zapomniane krajobrazy pamięci - cmentarze protestanckie w Wielkopolsce po 1945 roku, red. J. Kołacki, I. Skórzyńska, Poznań 2017. 
Domańska E., Historie niekonwencjonalne. Refleksja o przesztości w nowej humanistyce, Poznań 2006.

Domańska E., Problem rzeczy we wspótczesnej archeologii, w: Rzeczy i ludzie. Humanistyka wobec materialności, red. J. Kowalewski, W. Piasek, M. Śliwa, Olsztyn 2008.

Duma P., Grób alienata. Pochówki dzieci nieochrzczonych, samobójców i skazańców w późnym średniowieczu i dobie wczesnonowożytnej, Kraków 2010.

Fenyk M.A., Kuszewska K., Flora opuszczonych sadyb gospodarskich Warmii, „Acta Scientarium Polonorum”, 9 (2), 2010.

Flis S., Dżuma na Mazurach $i$ Warmii w latach 17081711, „Komunikaty Mazursko-Warmińskie”, 4, 1960.

GIS. Obszary zastosowań, red. B. Nowak, Warszawa 2007.

Knercer W., Ślady na ziemi-cmentarze, w: Nekropolie Warmii i Mazur, red. W. Knercer, B. Wacławik, Olsztyn 2016.

Kołacki J., Koncepcja badania cmentarzy protestanckich w Wielkopolsce. Studium przypadku Wolsztyn, w: Cmentarze nieistniejacych cmentarzy. Ewangelickie dziedzictwo kulturowe w Wolsztynie (w 500. rocznice reformacji), red. J. Kołacki, Poznań 2018.

Kotas M., Stowo wstępne, w: Nim catkowicie znikną. Cmentarze ewangelickie w powiecie poznańskim, red. J. Kołacki, Poznań 2018.

Kula M., Nośniki pamięci historycznej, Warszawa 2002. Liżewska I., Wstęp, w: T. Żurkowska, Mazurskie cmentarze. Symbole w Krajobrazie, Olsztyn 2008.

Łaguna W., Sieć osadnicza Ziemi Warminskiej - geneza i ewolucja do stanu obecnego, w: Spoteczeństwo, środowisko, gospodarka i krajobraz kulturowy Warmii w roku Ignacego Krasickiego, Olsztyn-Lidzbark Warmiński 2001.

Ławrynowicz O., Archaeology of us and the local identity. An interdisciplinary context, „Acta Universitatis Lodziensis. Folia Archaeologica”, 34, 2019.

Majdecka-Strzeżek A., Ogrody wiecznej pamięci w krajobrazie kulturowym, „Kwartalnik Architektury i Urbanistyki PAN”, 61 (3), 2016.

Majewska A., Continuity and decline. Temporal expression of denominational cemeteries in contemporary times, „Acta Universitatis Lodziensis. Folia Archaeologica”, 34, 2019.

Majewska A., Depopulated localities of former East Prussia as isolated components of the landscape structure in the form of clusters of high vegetation, "Journal of Geography, Politics and Society", 9 (4), 2019.

Majewska A., Relikty zaniktych jednostek osadniczych na pograniczu mazursko-mazowieckim. Interdyscyplinarny projekt badawczy, „Acta Universitatis Lodziensis. Folia Archaeologica”, 32, 2017.
Majewska A., Surface prospection of burial grounds and new research tools (on the example of the study of changes in cemetery boundaries), ,Journal of Geography, Politics and Society”, 7 (1), 2017.

Majewska A., Zanikte osadnictwo w granicach powiatu piskiego, Łódź 2018, mps pracy magisterskiej, Uniwersytet Łódzki.

Migoń P., Geomorfologia, Warszawa 2006.

Modern material culture and archaeology of us, ed. R.A. Gould, M.B. Schiffer, New York 1981.

Myga-Piątek U., Pamięć krajobrazu - zapis dziejów w przestrzeni, „Studia Geohistorica”, 3, 2015.

Nekropolie Warmii i Mazur, red. W. Knercer, B. Wacławik, Olsztyn 2016.

Nim catkowicie znikna. Cmentarze ewangelickie $w$ powiecie poznańskim, red. J. Kołacki, Poznań 2018.

Olszewski R., Numeryczne modele rzeźby terenu i powierzchni statystycznych, w: GIS. Obszary zastosowan, red. B. Nowak, Warszawa 2007.

Plit J., Analiza historyczna jako źródto informacji o środowisku przyrodniczym, „Problemy Ekologii Krajobrazu", 16, 2006.

Rydzewska A., Zabytkowe cmentarze ewangelickie pótnocnej Wielkopolski, Poznań 2012.

Rzeczy i ludzie. Humanistyka wobec materialności, red. J. Kowalewski, W. Piasek, M. Śliwa, Olsztyn 2008.

Spoteczeństwo, środowisko, gospodarka i krajobraz kulturowy Warmii w roku Ignacego Krasickiego, Olsztyn-Lidzbark Warmiński 2001.

Srokowski S., Prusy Wschodnie. Kraj i ludzie, Warszawa 1929.

Szulc H., Morfogenetyczne typy osiedli wiejskich na Pomorzu Zachodnim, Warszawa 1988.

Topographische Karte Messtischblatt, 1:25 000, Berlin 1880-1944.

Wadyl S., Niektóre elementy wyobrażeń religijnych Prusów $i$ ich trwanie $w$ czasach krzyżackich, „Komunikaty Mazursko-Warmińskie”, 2, 2010.

Wałkowska J., Cmentarze ewangelickie z perspektywy archeologii: problemy i możliwości badawcze, w: „Ziemia skrywa kości". Zapomniane krajobrazy pamięcicmentarze protestanckie $w$ Wielkopolsce po 1945 roku, red. J. Kołacki, I. Skórzyńska, Poznań 2017.

Zalewska A.I., Archeologia czasów wspótczesnych w Polsce. Tu i teraz, w: Archeologia wspótczesności. Pierwszy Kongres Archeologii Polskiej, t. 1, red. A.I. Zalewska, Warszawa 2016.

Zalewska B., Klon: przyczynek do problematyki ochrony uktadów ruralistycznych województwa warmińsko-mazurskiego, „Rocznik Mazurski”, 6, 2002.

Zawiła M., Dziedziczynienie przedwojennych cmentarzy na terenach postmigracyjnych Polski, Kraków 2019. 
„Ziemia skrywa kości”. Zapomniane krajobrazy pamięci - cmentarze protestanckie $w$ Wielkopolsce po 1945 roku, red. J. Kołacki, I. Skórzyńska, Poznań 2017.

Żurkowska T., Mazurskie cmentarze. Symbole w krajobrazie, Olsztyn 2008.
Żurkowska T., Roślinność opuszczonych mazurskich cmentarzy, jej bogactwo i symbolika, w: Nekropolie Warmii i Mazur, red. W. Knercer, B. Wacławik, Olsztyn 2016.

Żurkowska T., Warto odwiedzić mazurskie cmentarzyki, „Znad Pisy”, 12, 2003.

\section{Material memory of the landscape of cemeteries in abandoned rural settlements in the Polish part of former East Prussia - selected issues}

\section{Summary}

Cemeteries constitute an interesting element of the presently abandoned urban settlements in the part of former East Prussia incorporated into Poland after 1945. Contained within their perimeters are important pieces of information on the past functioning of the depopulated localities. The present article discusses the issue of identification and distribution of burial sites on the researched area through a comparative analysis of cartographic materials. The reference sources used in the analysis were sheets from the map Topographische Karte Messtischblatt produced in the 1920s-1940s and contemporary orthophoto maps. Detailed analyses were carried out with the use of hGIS technology, including the use of data on land topography obtained through airborne laser scanning.

Even though Evangelical cemeteries are one of the most recognisable elements of the local cultural landscape and constitute a symbol of former Protestant Prussia, not every single settlement had its own separate burial site. Cemeteries accompany $19 \%$ (149) of all presently depopulated settlements in the researched area. The highest number of burial sites (85) was located in the territory of villages and localities, while 34 formed part of historical manor estates and 12 - of farming estates. Cemeteries were also located by eight forester's lodges. Most burial sites are situated on local land elevations. A morphological feature distinguishing the discussed sites are earth bunds around their perimeter and stone mounds marking their borders. Most of them have regular, geometrical shapes, primarily rectangular. More unusual forms can be found mostly at smaller family cemeteries. Burial sites were established at an average distance of 250 to 350 metres from the nearest buildings. Very rarely were cemeteries founded inside the settlement area.

Cemeteries in abandoned localities are first and foremost objects standing out from the rest of the landscape, whose structures are an amalgam of numerous elements with strong symbolical meanings. This is evidenced by the results of the analysis of the location and spatial structure of the sites presented in the paper.

Anna Majewska - archeolog i geograf, doktorantka w Katedrze Geografii Politycznej, Historycznej i Studiów Regionalnych Wydziału Nauk Geograficznych Uniwersytetu Łódzkiego. Jej zainteresowania badawcze koncentrują się na zagadnieniach z zakresu geografii politycznej i historycznej, w szczególności dotyczących dziedzictwa kulturowego i przemian osadniczych na obszarach wiejskich. Obroniona przez nią praca magisterska nt. żydowskiego dziedzictwa religijnego w przestrzeni województwa śląskiego została nagrodzona m.in. w Konkursie im. Majera Bałabana organizowanym przez Żydowski Instytut Historyczny w Warszawie. Obecnie kieruje projektem pt. „Pamięć krajobrazu zanikających miejscowości z terenu dawnych Prus Wschodnich - materialny wymiar przerwania ciągłości osadnictwa", realizowanym w ramach grantu Preludium Narodowego Centrum Nauki (anna.majewska@op.pl) 
Anna Majewska - archaeologist and geographer, PhD student at the Department of Political and Historical Geography and Regional Studies, Faculty of Geographical Sciences, University of Łódź. Her research interests focus on political and historical geography, in particular issues concerning cultural heritage and transformations of settlements in rural areas. Her MA thesis on Jewish historical heritage in Śląskie Voivodeship received several awards, including a prize in the Majer Bałaban Contest organised by the Jewish Historical Institute in Warsaw. She is currently heading the project titled "Memory of the Landscape of Disappearing Localities in Former East Prussia - Material Dimension of Interruption in Settlement Continuity" ("Pamięć krajobrazu zanikających miejscowości z terenu dawnych Prus Wschodnich - materialny wymiar przerwania ciągtości osadnictwa") carried out as part of the Preludium grant of the National Science Centre (anna.majewska@op.pl) 